\title{
Adult-onset cervical dystonia, DYT23 type
}

INSERM

\section{Source}

INSERM. (1999). Orphanet: an online rare disease and orphan drug data base. Adultonset cervical dystonia, DYT23 type. ORPHA:420492

Adult-onset cervical dystonia, DYT 23 type is a rare, genetic, isolated dystonia characterized by adult-onset, non-progressive, focal cervical dystonia typically manifesting with torticollis and occasionally accompanied by mild head tremor and essential-type limb tremor. 